\title{
Clinical benefits and adverse effects of genetically-elevated free testosterone levels: a Mendelian randomization analysis
}

Pedrum Mohammadi-Shemirani ${ }^{1,2,3}$, Michael Chong MSc ${ }^{1,2,4}$, Marie Pigeyre MD PhD ${ }^{1,6}$, Robert W. Morton $\mathrm{PhD}^{5}$, Hertzel C. Gerstein MD MSc ${ }^{1,6}$, Guillaume Paré MD MSc*1,2,7,8

1 Population Health Research Institute, David Braley Cardiac, Vascular and Stroke Research Institute, 237 Barton Street East, Hamilton, ON L8L 2X2, Canada

2 Thrombosis and Atherosclerosis Research Institute, David Braley Cardiac, Vascular and Stroke Research Institute, 237 Barton Street East, Hamilton, ON L8L 2X2, Canada

3 Department of Medical Sciences, McMaster University, 1280 Main Street West, Hamilton ON L8S 4K1, Canada

4 Department of Biochemistry and Biomedical Sciences, McMaster University, 1280 Main Street West, Hamilton ON L8S 4K1, Canada

5 Department of Kinesiology, McMaster University, 1280 Main Street West, Hamilton ON L8S 4K1, Canada

6 Department of Medicine, McMaster University, Hamilton Health Sciences, Hamilton, ON L8S 4K1, Canada

7 Department of Pathology and Molecular Medicine, McMaster University, Michael G. DeGroote School of Medicine, 1280 Main Street West, Hamilton ON L8S 4K1, Canada

8 Department of Health Research Methods, Evidence, and Impact, McMaster University, 1280 Main Street West, Hamilton ON L8S 4K1, Canada

* Corresponding author 
medRxiv preprint doi: https://doi.org/10.1101/19005132; this version posted August 29, 2019. The copyright holder for this preprint (which was not certified by peer review) is the author/funder, who has granted medRxiv a license to display the preprint in perpetuity. It is made available under a CC-BY 4.0 International license.

\begin{abstract}
BACKGROUND: Testosterone products are increasingly being prescribed to males for a variety of possible health benefits but the causal relationship between testosterone and health-related outcomes is unclear. Evidence from well-powered randomized controlled trials are difficult to obtain, particularly regarding effects on long-term or adverse outcomes. We sought to determine the effects of genetically-predicted calculated free testosterone (CFT) on 23 health outcomes. METHODS: Genetic variants associated with CFT were determined from 136,531 white British males in the UK Biobank. One-sample and two-sample Mendelian randomization (MR) analyses were performed to infer the effects of genetically-predicted CFT on 23 health outcomes selected based on relevance with known or suspected effects of testosterone therapy.

FINDINGS: In males from the UK Biobank, 81 independent genetic variants were associated with CFT levels at genome-wide significance $\left(\mathrm{p}<5 \times 10^{-8}\right)$. Each $0.1 \mathrm{nmol} / \mathrm{L}$ increase in geneticallypredicted CFT was associated with clinical benefits on increased heel bone mineral density $(0.053$ $\mathrm{SD} ; 95 \% \mathrm{CI}=0.038$ to $\left.0.068 ; \mathrm{p}=8.77 \times 10^{-12}\right)$ and decreased body fat percentage $(-1.86 \% ; 95 \% \mathrm{CI}$ $=-2.35$ to $\left.-1.37 ; \mathrm{p}=1.56 \times 10^{-13}\right)$, and adverse effects on increased risk of prostate cancer $(\mathrm{OR}=1.28$; $95 \% \mathrm{CI}=1.11$ to $\left.1.49 ; \mathrm{p}=1.0 \times 10^{-3}\right)$, risk of androgenic alopecia $(\mathrm{OR}=1.82 ; 95 \% \mathrm{CI}=1.55$ to 2.14 ; $\left.\mathrm{p}=3.52 \times 10^{-13}\right)$, risk of benign prostate hyperplasia $(\mathrm{BPH})(\mathrm{OR}=1.81 ; 95 \% \mathrm{CI}=1.34$ to 2.44; $\left.\mathrm{p}=1.05 \times 10^{-4}\right)$ and hematocrit percentage $\left(1.49 \% ; 95 \% \mathrm{CI}=1.24\right.$ to $\left.1.74 ; \mathrm{p}=3.49 \times 10^{-32}\right)$.

CONCLUSIONS: Long-term elevated free testosterone levels cause prostate cancer, BPH, and hair loss while reducing body fat percentage and increasing bone density. It also has a neutral effect on type 2 diabetes, cardiovascular and cognitive outcomes. Well powered randomized trials are needed to address the effects of shorter term use of exogenous testosterone on these outcomes.
\end{abstract}


medRxiv preprint doi: https://doi.org/10.1101/19005132; this version posted August 29, 2019. The copyright holder for this preprint (which was not certified by peer review) is the author/funder, who has granted medRxiv a license to display the preprint in perpetuity. It is made available under a CC-BY 4.0 International license .

\section{INTRODUCTION}

In developed countries, rising rates of both serum testosterone level testing and therapy initiation have been observed among older male patients ${ }^{1,2}$. In the USA, it is estimated $1.5-1.7 \%$ of males are currently prescribed testosterone ${ }^{3,4}$. Randomized clinical trials (RCT) have attempted to elucidate the benefits and risks of testosterone therapy ${ }^{5,6}$. These studies identified short-term beneficial effects on $\mathrm{BMD}^{7}$, sexual function ${ }^{8}$, body fat and muscle mass ${ }^{9}$, and anemia $^{10,11}$; potential adverse effects on erythrocytosis ${ }^{10,11}$, venous thrombosis ${ }^{12}$ and coronary artery plaque ${ }^{13}$; and no effects on cognitive function ${ }^{14}$, liver fat ${ }^{15}$, fatigue ${ }^{8}$, or haemoglobin $\mathrm{A} 1_{\mathrm{c}}$ $\left(\mathrm{HbA} 1_{\mathrm{c}}\right)^{16}$. However, given the logistic and financial challenges involved in a well-powered RCT with appropriate follow-up, there is unlikely to be satisfactory evidence regarding long-term effects and risks of adverse outcomes, such as myocardial infarction (MI), stroke and cancer ${ }^{5}$. Given the rates of testosterone prescription, efforts to resolve the causal effects of testosterone on health outcomes have important public health implications ${ }^{6}$.

Mendelian randomization (MR) is a technique for causal inference that leverages the random allocation of genetic variants to infer the unconfounded relationship between an exposure and outcome. Similar to the random assignment of participants to experimental groups in a RCT, genetic variants are randomly allocated at meiosis ${ }^{17}$. For instance, if individuals genetically randomized to produce higher testosterone develop different rates of cardiovascular disease (CVD), then MR analysis supports a causal effect of testosterone on risk of CVD (Supplementary Figure 1). Notably, this technique has previously replicated RCT findings, among others demonstrating causal roles for LDL cholesterol and dysglycemia on CVD risk ${ }^{18,19}$. Prior MR studies investigating the effects of testosterone have demonstrated harmful effects on lipid levels but inconsistent effects on $\mathrm{CVD}^{20,21}$. However, these studies have been limited by the small number of genetic variants and the use of total testosterone as opposed to free testosterone 
medRxiv preprint doi: https://doi.org/10.1101/19005132; this version posted August 29, 2019. The copyright holder for this preprint (which was

levels. Free testosterone is better representative of the effects of testosterone in the body, since total testosterone encompasses biologically inactive testosterone bound to transporter proteins ${ }^{22}$. Accordingly, studies have shown the main transporter of testosterone, sex hormone-binding globulin (SHBG), is a strong predictor of CVD risk factors independent of total testosterone and may be a source of confounding ${ }^{23}$. To date, there have been no MR studies investigating the effects of free testosterone.

We hypothesized that MR analyses would enable us to estimate the causal effects of longstanding exposure to high levels of free testosterone on selected health-related outcomes that have been previously investigated in randomized clinical trials of testosterone therapy. We first conducted a genome-wide association study (GWAS) for calculated free testosterone (CFT) in male participants of the UK Biobank $(n=136,531)$ cohort to identify genetic determinants of free testosterone levels. Then, using MR, we investigated the causal effects of lifelong genetically-elevated free testosterone levels on various health outcomes, encompassing: expected clinical benefits (physical activity, strength, fat-free body mass, body fat, BMD, dementia, depression) and potential adverse effects (androgenic alopecia, haematocrit, type 2 diabetes, liver fat, prostate cancer, blood pressure, CVD, heart failure, ischemic stroke) (Figure 1) $)^{5-10,14-16,24}$.

\section{METHODS}

\section{Study Population - UK Biobank}

The UK Biobank is a large-scale longitudinal cohort study that recruited over 500,000 people between the ages of 37-73 across the United Kingdom from 2006-2010 25 . Extensive health information was collected through self-reported medical histories and physical measures at recruitment, and ongoing health developments through linked electronic health records. UK Biobank received ethical approval from the North West Multi-Centre Research Ethics 
medRxiv preprint doi: https://doi.org/10.1101/19005132; this version posted August 29, 2019. The copyright holder for this preprint (which was not certified by peer review) is the author/funder, who has granted medRxiv a license to display the preprint in perpetuity. It is made available under a CC-BY 4.0 International license .

Committee (REC reference: 11/NW/0382). This research was conducted using the UK Biobank under Application Number 15255.

\section{Calculation of Free Testosterone}

For our analyses, males in the UK Biobank were excluded if they had reported taking any androgen medication at recruitment based on field ID $20003(n=2,137)$. Free testosterone was calculated using the Vermeulen equation ${ }^{22}$ with levels of serum total testosterone, SHBG, and albumin measured at recruitment. CFT levels were winsorized such that outlying values greater or less than 4 standard deviations (SD) away from the mean in males were set to 4 SD.

\section{Genome-wide Association Study of Calculated Free Testosterone}

For genome-wide association testing, UK Biobank samples were restricted to a subset of white British ancestry that were unrelated (greater than $3^{\text {rd }}$ degree). Genetic variants were restricted to those present in the Haplotype Reference Consortium panel ${ }^{26}$ with imputation quality greater than 0.6 , no deviation from Hardy-Weinberg equilibrium $\left(\mathrm{p}>1 \times 10^{-10}\right)$ and minor allele frequency greater than $0.1 \%$ (equivalent to approximately 150 copies of the minor allele in this male subset). After these exclusions, almost 12 million directly genotyped or imputed genetic variants were left in the model. BGENIE v1.2 ${ }^{27}$ was used to run an additive genetic model in male participants from this subset of the UK Biobank. The model was adjusted for age, age $^{2}$, chip type, assessment centre, and the first 20 genetic principal components.

Genetic variants near the $S H B G$ gene have been shown to alter binding affinity for testosterone thereby violating assumptions of the Vermeulen equation ${ }^{28}$, and SHBG risks having pleiotropic effects through its binding of other sex hormones. Therefore, we tested genetic variants associated with CFT reaching genome-wide significance (GWS) $\left(\mathrm{p} \leq 5 \times 10^{-8}\right)$ for evidence of association with natural log-transformed SHBG levels in the same subset of the UK Biobank (Supplementary Figure 2). Any genetic variants associated with $\mathrm{SHBG}(\mathrm{p}<0.05)$ were 
medRxiv preprint doi: https://doi.org/10.1101/19005132; this version posted August 29, 2019. The copyright holder for this preprint (which was

removed. To arrive at an independent set of genetic variants, variants associated with CFT but not associated with SHBG were pruned based on linkage disequilibrium (LD) at a threshold of $r^{2}<0.01$. The reference panel for LD was derived from 1000 Genomes Europeans phase $3^{29}$.

\section{Selection of Health-Related UK Biobank Outcomes}

Thirty-one health outcomes were selected based on relevance with known or suspected effects of testosterone therapy, and they were classified based on expected beneficial or adverse effects from randomized clinical trial data. Outcomes with expected beneficial effects were fractures at any site, heel BMD, body fat percentage, dementia, depression, erectile dysfunction, handgrip strength, physical activity level measured by wrist-worn accelerometer, and whole body fat-free mass. Outcomes with potential adverse effects were stroke, androgenic alopecia, arterial embolism and thrombosis, benign prostate hyperplasia (BPH), blood pressure, glucose, haematocrit percentage, haemoglobin A1c, heart failure, liver fat, prostate cancer, MI, testicular cancer, type 2 diabetes (T2D), and venous thromboembolism. Detailed descriptions of all outcomes are shown in Supplementary Table 1 and Supplementary Methods. Given the small number of cases for several outcomes, power calculations were performed for MR analyses using a significance level of 0.05 , and any outcomes with detectable odds ratios less than 0.5 or greater than 2 per $0.1 \mathrm{nmol} / \mathrm{L}$ at $80 \%$ power were excluded (Supplementary Table 2$)^{30}$. After these exclusions, there were 23 health outcomes that remained for subsequent MR analyses in this study.

The association of all independent genetic variants associated with CFT were determined for each of the 23 outcomes using additive genetic models in BGENIE v1.2 27 and adjusted for the same covariates as the model for CFT. For dichotomous outcomes, odds ratios were approximated as previously described ${ }^{31}$ by converting linear effect estimates to log-odds scale using: 
medRxiv preprint doi: https://doi.org/10.1101/19005132; this version posted August 29, 2019. The copyright holder for this preprint (which was

$$
\log (O R)=\frac{\beta}{k(1-k)} \text {, where } k \text { is the proportion of cases for the given outcome }
$$

\section{Mendelian randomization - One-sample design}

For each of the 23 outcomes, one-sample MR analysis was used to combine the effect of each independent genetic variant on CFT with its effect on the outcome. Weighted median method was used to infer the causal effect of CFT on the outcome, which selects the median causal estimate after weighing estimates of each individual genetic variant according to their variance $^{32}$. The resulting estimate is robust to horizontal pleiotropy when at least $50 \%$ of weights belong to valid genetic variants ${ }^{32}$. Given the polygenic nature of testosterone and potential for pleiotropy, this method was selected to ensure reliable estimates. Outcomes were deemed statistically significant after adjusting for multiple hypothesis testing of 23 health outcomes using Bonferroni correction $\left(\mathrm{p}<2.17 \times 10^{-3}\right)$. Effect estimates were reported per $0.1 \mathrm{nmol} / \mathrm{L}$ increase in CFT levels based on approximate changes in response to testosterone therapy ${ }^{33,34}$.

Sensitivity analyses ensured effects weren't driven by any single variant. For statistically significant outcomes, leave-one-out analyses was performed where MR analysis was repeated after each genetic variant was excluded. Furthermore, genetic variants were assessed for "weak instrument bias", which can result in biased estimates if genetic variants don't explain enough variance in CFT levels ${ }^{35}$. The F-statistic was 4952 for the genetic variants used in this MR, which was considered a strong instrument based on the recommended threshold of greater than $10^{35}$.

\section{Mendelian randomization - Two-sample design}

Given the limited number of cases in the UK Biobank for dichotomous outcomes, the data were supplemented using results from 10 publicly-available studies published elsewhere. Data from these independent studies were analyzed using a two-sample MR approach with the 81 genetic variants associated with CFT from the UK Biobank, and the association of each CFT- 
medRxiv preprint doi: https://doi.org/10.1101/19005132; this version posted August 29, 2019. The copyright holder for this preprint (which was

associated genetic variant with the outcome was obtained from the published GWAS. Generally, two-sample MR has the advantage of enabling the use of larger sample sizes and biases estimates towards the null under weak instrument conditions. We identified 10 publicly available GWAS summary statistics corresponding to dichotomous outcomes used in the one-sample MR analysis (Supplementary Table 3$)^{36-41}$. For each outcome, MR analysis was similarly performed using the weighted median method. For male-specific outcomes, MR effect estimates from two-sample and one-sample analyses were meta-analysed under a fixed effects model using the meta package in $\mathrm{R}^{42}$.

\section{Mendelian randomization - Age-stratified}

Given age-related decline in testosterone levels and selection criteria in RCTs, we stratified the UK Biobank male participants into two groups based on age at recruitment above or below 65 years to investigate differential effects of free testosterone levels in these age groups. For significant outcomes from the MR analysis $\left(\mathrm{p}<2.17 \times 10^{-3}\right)$, one-sample MR analysis was repeated as described previously separately in each subgroup to interrogate the effect of CFT on the given outcome according to age. P-values for heterogeneity between age groups were calculated under a fixed effects model in the meta package.

All MR analyses were implemented using the TwoSampleMR package ${ }^{43}$. All statistical analyses were performed under $\mathrm{R}$ version 3.6.0, unless otherwise specified. A two-sided p-value less than $5 \times 10^{-8}$ for GWAS, $2.17 \times 10^{-3}(0.05 / 23$ outcomes $)$ for standard MR analyses, and 0.05 for heterogeneity in age-stratified MR analyses was considered statistically significant.

\section{Patient and public involvement}

This research was done without patient involvement. Patients were not invited to comment on the study design and were not consulted to develop patient relevant outcomes or 
medRxiv preprint doi: https://doi.org/10.1101/19005132; this version posted August 29, 2019. The copyright holder for this preprint (which was

interpret the results. Patients were not invited to contribute to the writing or editing of this document for readability or accuracy.

\section{RESULTS}

\section{Genetic determinants of calculated free testosterone in males}

There were 158,870 males in the unrelated white, British subset of the UK Biobank cohort. To calculate free testosterone levels, we excluded individuals that had missing levels of total testosterone, SHBG and albumin, or self-reported taking androgen medications. After these exclusions, the study population consisted of 136,531 males with an average CFT of $0.21 \mathrm{nmol} / \mathrm{L}$ (Supplementary Table 4 and Supplementary Figure 3).

There were 9,150 genetic variants associated with CFT that reached GWS $\left(\mathrm{p}<5 \times 10^{-8}\right)$ (Supplementary Figure 4). After removing genetic variants associated with natural-log transformed SHBG and keeping only independent signals, there were 81 genetic variants carried forward for subsequent genetic analyses (Supplementary Table 5). Altogether, these 81 genetic variants explained $3.4 \%$ of the total variance of CFT levels in males from the UK Biobank.

\section{Effect of free testosterone on 23 health outcomes using Mendelian randomization analysis}

In males from the UK Biobank, sample size for the quantitative risk factors ranged from 1,595 to 156,403 , while number of cases for dichotomous outcomes ranged from 1,003 to 70,283

(Table 1). After adjusting for the 23 outcomes tested, one-sample MR analysis identified significant effects of CFT on haematocrit percentage, body fat percentage, heel BMD, androgenic alopecia, and BPH (Table 1). Each $0.1 \mathrm{nmol} / \mathrm{L}$ higher CFT had beneficial effects on increased heel $\mathrm{BMD}\left(0.053 \mathrm{SD} ; 95 \% \mathrm{CI}=0.038\right.$ to $\left.0.068 ; \mathrm{p}=8.77 \times 10^{-12}\right)$ and decreased body fat percentage $\left(-1.86 \% ; 95 \% \mathrm{CI}=-2.35\right.$ to $\left.-1.37 ; \mathrm{p}=1.56 \times 10^{-13}\right)$, but deleterious effects on increased haematocrit percentage $\left(1.49 \% ; 95 \% \mathrm{CI}=1.24\right.$ to $\left.1.74 ; \mathrm{p}=3.49 \times 10^{-32}\right)$, risk of androgenic 
medRxiv preprint doi: https://doi.org/10.1101/19005132; this version posted August 29, 2019. The copyright holder for this preprint (which was not certified by peer review) is the author/funder, who has granted medRxiv a license to display the preprint in perpetuity. It is made available under a CC-BY 4.0 International license .

alopecia $\left(\mathrm{OR}=1.82 ; 95 \% \mathrm{CI}=1.55\right.$ to $\left.2.14 ; \mathrm{p}=3.52 \times 10^{-13}\right)$ and risk of $\mathrm{BPH}(\mathrm{OR}=1.81 ; 95 \% \mathrm{CI}=$ 1.34 to $\left.2.44 ; \mathrm{p}=1.05 \times 10^{-4}\right)$. Leave-one-out analyses did not identify any outlying individual genetic variants responsible for the observed effects on any significant outcomes.

To increase the statistical power of the MR analyses, two-sample MR analysis was performed for dichotomous outcomes using independent summary statistics from GWAS with greater numbers of cases. Male-specific summary statistics were available for prostate cancer from the Prostate Cancer Association Group to Investigate Cancer-Associated Alterations in the Genome (PRACTICAL) consortium, and combined male and female summary statistics for 10 other dichotomous outcomes (Supplementary Table 3). The effect of CFT was directionally consistent with the one-sample MR analysis for prostate cancer. Given no overlap between the samples in the UK Biobank and PRACTICAL consortium summary statistics, effect estimates were meta-analysed and reached statistical significance $(\mathrm{OR}=1.28 ; 95 \% \mathrm{CI}=1.11$ to 1.49 ; $\left.\mathrm{p}=1.0 \times 10^{-3}\right)$. Similarly, there was a consistent null effect observed for ischemic stroke and other stroke subtypes, Alzheimer's disease, and T2D (Supplementary Table 6), but these effect estimates were not meta-analysed due to lack of available male-specific summary statistics.

\section{Differential effects of free testosterone on health outcomes according to age subgroups}

To identify differential effects of CFT between age groups, we repeated MR analysis in males from the UK Biobank stratified according to participant's age below or above 65 years. Age-specific effects of CFT were then determined for statistically significant $\left(\mathrm{p}<2.17 \times 10^{-3}\right)$ outcomes from MR analyses. Genetically-elevated CFT showed a risk-conferring effect on BPH $\left(\mathrm{OR}=1.80 ; 95 \% \mathrm{CI}=1.22\right.$ to $\left.2.65 ; \mathrm{p}=2.89 \times 10^{-3}\right)$ and prostate cancer $(\mathrm{OR}=2.02 ; 95 \% \mathrm{CI}=1.29$ to $3.65 ; \mathrm{p}=2.10 \times 10^{-3}$ ) specific to males under 65 years of age ( $\mathrm{pheterogeneity}=0.019$ for $\mathrm{BPH}$ and 0.038 for prostate cancer) (Supplementary Figure 5). Androgenic alopecia, haematocrit 
medRxiv preprint doi: https://doi.org/10.1101/19005132; this version posted August 29, 2019. The copyright holder for this preprint (which was

percentage, body fat percentage, and heel BMD showed no significantly different effect in participants above versus below 65 years of age.

\section{DISCUSSION}

We herein perform an MR analysis of CFT to identify effects of elevated endogenous free testosterone in males on 23 health outcomes. MR analyses demonstrated that each 0.1 nmol/L increase in CFT was associated with adverse effects on increased risk of prostate cancer, risk of androgenic alopecia, risk of $\mathrm{BPH}$, and hematocrit percentage, but beneficial effects on increased heel BMD and decreased body fat percentage. These findings are consistent with shortterm effects in randomized trials of testosterone therapy, and opposite effects of $5 \alpha$-reductase inhibitors - inhibiting the conversion of testosterone into the more potent dihydrotestosterone as a treatment for androgenic alopecia and $\mathrm{BPH}^{6,44,45}$. Furthermore, $\mathrm{MR}$ analyses showed no effect of free testosterone on several hard endpoints, such as dementia, MI, stroke, fractures, and T2D. Accordingly, these results cast doubt on claims of cardiovascular risk or benefit for testosterone therapy ${ }^{46}$.

After meta-analysis of MR results from the UK Biobank and PRACTICAL consortium studies, there was a statistically significant risk-conferring effect of free testosterone on prostate cancer $\left(\mathrm{p}=1.0 \times 10^{-3}\right)$. Prostate cancer is the leading cause of cancer and second leading cause of cancer death among men in the USA ${ }^{47}$. Androgen suppression has long been used as treatment for both $\mathrm{BPH}^{48}$ and prostate cancer ${ }^{45}$. However, there is inconclusive $\mathrm{RCT}$ evidence regarding the effects of elevated testosterone via either endogenous or exogenous means on development of $\mathrm{BPH}$ or prostate cancer ${ }^{49}$. These MR results suggest 1.3 -fold increased risk of prostate cancer per $0.1 \mathrm{nmol} / \mathrm{L}$ increase in free testosterone levels, which is comparable to changes observed after initiation of testosterone therapy ${ }^{33,34}$. Moreover, age-stratified analyses provided suggestive 
medRxiv preprint doi: https://doi.org/10.1101/19005132; this version posted August 29, 2019. The copyright holder for this preprint (which was

evidence of a specific effect on BPH and prostate cancer in individuals under 65 years of age.

These findings warrant further investigation in clinical trials of exogenous testosterone supplementation and calls for greater scrutiny in this patient population.

There are several limitations of this study. First, an assumption of the MR analysis is that the effect of the genetic variant on the outcome occurs only through free testosterone levels, such that there are no pleiotropic effects through other proteins or mechanisms ${ }^{17}$. This concern was minimized by the use of multiple genetic variants, which limited the likelihood of a common alternative pathway confounding our observation. Moreover, we performed standard sensitivity analyses and excluded genetic variants associated with SHBG levels, which is a potential source of pleiotropy through its effects on other hormones. Additionally, one-sample MR may be susceptible to bias towards the confounded estimate if the genetic variants are "weak instruments", which can occur if the genetic variants don't explain enough of the variance in free testosterone levels ${ }^{35}$. To address this concern, we confirmed the selected genetic variants were strong instruments using a common threshold in MR literature $(\mathrm{F} \text {-statistic }>10)^{35}$. Furthermore, two-sample MR analyses afforded larger sample sizes for certain dichotomous outcomes, and yielded a risk-conferring effect of CFT on prostate cancer and nonsignificant effects on Alzheimer's disease, coronary heart disease, stroke subtypes, and T2D. However, besides prostate cancer, these results should be interpreted with caution as these GWAS summary statistics didn’t provide sex-specific genetic estimates (Supplementary Table 3). Consequently, if the effect of CFT genetic associations are male-specific, the causal effect of free testosterone in males may have been diluted or counteracted by the inclusion of females. Finally, these MR results represent lifelong effects of endogenous free testosterone and may not necessarily reflect 
medRxiv preprint doi: https://doi.org/10.1101/19005132; this version posted August 29, 2019. The copyright holder for this preprint (which was not certified by peer review) is the author/funder, who has granted medRxiv a license to display the preprint in perpetuity.

It is made available under a CC-BY 4.0 International license .

effects of exogenous testosterone therapy, which can vary in duration, age of initiation, and dosage.

Taken altogether, the decision to initiate long-term testosterone use warrants careful consideration of benefits and risk. From a lifestyle perspective, beneficial effects on body fat percentage and sexual function should be weighed against detrimental effects on androgenic alopecia and adverse urinary symptoms arising from BPH. From a clinical perspective, there may be a beneficial effect on hematocrit percentage and BMD but no significant effects on hard clinical endpoints (e.g., CVD, fracture, and T2D) except a risk-conferring effect on prostate cancer with evidence of a possible effect specific to younger males. Ultimately, well-designed and appropriately powered RCTs, such as the ongoing TRAVERSE trials (clinicaltrials.gov, NCT03518034), are necessary to conclusively address questions of safety and effectiveness of testosterone therapy. However, as demonstrated in this study, genetically-informed analyses can be powerful tools to aid health professionals in prioritizing allocation of limited resources towards investigating the most pressing questions.

\section{ACKNOWLEDGEMENTS}

The authors are thankful for all the participants that contributed to the UK Biobank study. Also, the authors would like to thank the CARDIoGRAMplusC4D, DIAGRAM, IGAP, MEGASTROKE, and PRACTICAL consortia for making summary statistics publicly-available for this work.

\section{DATA AVAILABILITY}


medRxiv preprint doi: https://doi.org/10.1101/19005132; this version posted August 29, 2019. The copyright holder for this preprint (which was not certified by peer review) is the author/funder, who has granted medRxiv a license to display the preprint in perpetuity.

It is made available under a CC-BY 4.0 International license .

Associations of genetic variants with calculated free testosterone in the UK Biobank are provided in the supplementary data. All other UK Biobank data is available by application directly to the UK Biobank. All other genome-wide association study summary statistics are publicly-available from the corresponding consortia: CARDIoGRAMplusC4D (http://www.cardiogramplusc4d.org/data-downloads/), DIAGRAM (https://www.diagramconsortium.org/downloads.html), IGAP (http://web.pasteurlille.fr/en/recherche/u744/igap/igap_download.php), MEGASTROKE (http://www.megastroke.org/download.html), and PRACTICAL (http://practical.icr.ac.uk/blog/?page id=8164).

\section{DECLARATION OF INTERESTS}

HCG reports research grants from Eli Lilly, AstraZeneca, Merck, Novo Nordisk, and Sanofi; honoraria for speaking from AstraZeneca, Boehringer Ingelheim, Eli Lilly, Novo Nordisk, and Sanofi; and consulting fees from Abbott, AstraZeneca, Boehringer Ingelheim, Eli Lilly, Merck, Novo Nordisk, Janssen, Sanofi, Kowa, and Cirius. No other potential conflicts of interest relevant to this article were reported.

\section{FUNDING}

MC was supported by a CIHR Frederick Banting and Charles Best Canada Graduate Scholarships Doctoral Award. MP was supported by the E.J. Moran Campbell Internal Career Research Award from McMaster University. RWM was supported by a CIHR Fellowship. HCG was supported by the McMaster-Sanofi Population Health Institute Chair in Diabetes Research and Care. GP was supported by the Canada Research Chair in Genetic and Molecular 
medRxiv preprint doi: https://doi.org/10.1101/19005132; this version posted August 29, 2019. The copyright holder for this preprint (which was not certified by peer review) is the author/funder, who has granted medRxiv a license to display the preprint in perpetuity.

It is made available under a CC-BY 4.0 International license.

Epidemiology and the Cisco Systems Professorship in Integrated Health Biosystems. The funders had no role in the design, analyses, interpretation of results, writing of the paper, or decision for publication. 
medRxiv preprint doi: https://doi.org/10.1101/19005132; this version posted August 29, 2019. The copyright holder for this preprint (which was not certified by peer review) is the author/funder, who has granted medRxiv a license to display the preprint in perpetuity. It is made available under a CC-BY 4.0 International license .

\section{REFERENCES}

1. Handelsman DJ. Global trends in testosterone prescribing, 2000-2011: expanding the spectrum of prescription drug misuse. Med J Aust. 2013;199(8):548-551. doi:10.5694/mja13.10111

2. Layton JB, Li D, Meier CR, et al. Testosterone Lab Testing and Initiation in the United Kingdom and the United States, 2000 to 2011. J Clin Endocrinol Metab. 2014;99(3):835842. doi:10.1210/jc.2013-3570

3. Baillargeon J, Kuo Y-F, Westra JR, Urban RJ, Goodwin JS. Testosterone Prescribing in the United States, 2002-2016. JAMA. 2018;320(2):200. doi:10.1001/jama.2018.7999

4. Jasuja GK, Bhasin S, Rose AJ. Patterns of testosterone prescription overuse. Curr Opin Endocrinol Diabetes Obes. 2017;24(3):240-245. doi:10.1097/MED.0000000000000336

5. Gagliano-Jucá T, Basaria S. Testosterone replacement therapy and cardiovascular risk. Nat Rev Cardiol. 2019;14(2):83-90. doi:10.1038/s41569-019-0211-4

6. Bhasin S, Brito JP, Cunningham GR, et al. Testosterone Therapy in Men With Hypogonadism: An Endocrine Society* Clinical Practice Guideline. J Clin Endocrinol Metab. 2018;103(5):1715-1744. doi:10.1210/jc.2018-00229

7. Snyder PJ, Kopperdahl DL, Stephens-Shields AJ, et al. Effect of Testosterone Treatment on Volumetric Bone Density and Strength in Older Men With Low Testosterone. JAMA Intern Med. 2017;177(4):471. doi:10.1001/jamainternmed.2016.9539

8. Snyder PJ, Bhasin S, Cunningham GR, et al. Effects of Testosterone Treatment in Older Men. N Engl J Med. 2016;374(7):611-624. doi:10.1056/NEJMoa1506119

9. Page ST, Amory JK, Bowman FD, et al. Exogenous Testosterone (T) Alone or with Finasteride Increases Physical Performance, Grip Strength, and Lean Body Mass in Older Men with Low Serum T. J Clin Endocrinol Metab. 2005;90(3):1502-1510. doi:10.1210/jc.2004-1933

10. Roy CN, Snyder PJ, Stephens-Shields AJ, et al. Association of Testosterone Levels With Anemia in Older Men. JAMA Intern Med. 2017;177(4):480.

doi:10.1001/jamainternmed.2016.9540

11. Basaria S, Coviello AD, Travison TG, et al. Adverse Events Associated with Testosterone Administration. N Engl J Med. 2010;363(2):109-122. doi:10.1056/NEJMoa1000485

12. $\mathrm{Xu} \mathrm{L}$, Schooling CM. Differential risks in men and women for first and recurrent venous thrombosis: the role of genes and environment: comment. J Thromb Haemost. 2015;13(5):884-886. doi:10.1111/jth.12862

13. Budoff MJ, Ellenberg SS, Lewis CE, et al. Testosterone treatment and coronary artery plaque volume in older men with low testosterone. JAMA. 2017;317(7):708-716. doi:10.1001/jama.2016.21043

14. Resnick SM, Matsumoto AM, Stephens-Shields AJ, et al. Testosterone Treatment and Cognitive Function in Older Men With Low Testosterone and Age-Associated Memory Impairment. JAMA. 2017;317(7):717. doi:10.1001/jama.2016.21044

15. Huang G, Bhasin S, Tang ER, et al. Effect of testosterone administration on liver fat in older men with mobility limitation: Results from a randomized controlled trial. Journals Gerontol - Ser A Biol Sci Med Sci. 2013;68(8):954-959. doi:10.1093/gerona/gls259

16. Mohler ER, Ellenberg SS, Lewis CE, et al. The Effect of Testosterone on Cardiovascular Biomarkers in the Testosterone Trials. J Clin Endocrinol Metab. 2018;103(2):681-688. doi:10.1210/jc.2017-02243

17. Davies NM, Holmes M V., Davey Smith G. Reading Mendelian randomisation studies: a 
guide, glossary, and checklist for clinicians. BMJ. 2018;362:k601. doi:10.1136/bmj.k601

18. Holmes M V., Asselbergs FW, Palmer TM, et al. Mendelian randomization of blood lipids for coronary heart disease. Eur Heart J. 2015;36(9):539-550. doi:10.1093/eurheartj/eht571

19. Ross S, Gerstein HC, Eikelboom J, Anand SS, Yusuf S, Paré G. Mendelian randomization analysis supports the causal role of dysglycaemia and diabetes in the risk of coronary artery disease. Eur Heart J. 2015;36(23):1454-1462. doi:10.1093/eurheartj/ehv083

20. Zhao J, Jiang C, Lam TH, et al. Genetically predicted testosterone and cardiovascular risk factors in men: a Mendelian randomization analysis in the Guangzhou Biobank Cohort Study. Int J Epidemiol. 2014;43(1):140-148. doi:10.1093/ije/dyt239

21. Schooling CM, Luo S, Au Yeung SL, et al. Genetic predictors of testosterone and their associations with cardiovascular disease and risk factors: A Mendelian randomization investigation. Int J Cardiol. 2018;267:171-176. doi:10.1016/j.ijcard.2018.05.051

22. Vermeulen A, Verdonck L, Kaufman JM. A Critical Evaluation of Simple Methods for the Estimation of Free Testosterone in Serum. J Clin Endocrinol Metab. 1999;84(10):36663672. doi:10.1210/jcem.84.10.6079

23. Canoy D, Barber TM, Pouta A, et al. Serum sex hormone-binding globulin and testosterone in relation to cardiovascular disease risk factors in young men: a populationbased study. Eur J Endocrinol. 2014;170(6):863-872. doi:10.1530/EJE-13-1046

24. Calof OM, Singh AB, Lee ML, et al. Adverse Events Associated With Testosterone Replacement in Middle-Aged and Older Men: A Meta-Analysis of Randomized, PlaceboControlled Trials. Journals Gerontol Ser A Biol Sci Med Sci. 2005;60(11):1451-1457. doi:10.1093/gerona/60.11.1451

25. Sudlow C, Gallacher J, Allen N, et al. UK Biobank: An Open Access Resource for Identifying the Causes of a Wide Range of Complex Diseases of Middle and Old Age. PLOS Med. 2015;12(3):e1001779. doi:10.1371/journal.pmed.1001779

26. McCarthy S, Das S, Kretzschmar W, et al. A reference panel of 64,976 haplotypes for genotype imputation. Nat Genet. 2016;48(10):1279-1283. doi:10.1038/ng.3643

27. Bycroft C, Freeman C, Petkova D, et al. Genome-wide genetic data on $\sim 500,000$ UK Biobank participants. bioRxiv. 2017. doi:10.1101/166298

28. Ohlsson C, Wallaschofski H, Lunetta KL, et al. Genetic Determinants of Serum Testosterone Concentrations in Men. Abecasis GR, ed. PLoS Genet. 2011;7(10):e1002313. doi:10.1371/journal.pgen.1002313

29. Altshuler DM, Durbin RM, Abecasis GR, et al. An integrated map of genetic variation from 1,092 human genomes. Nature. 2012;491(7422):56-65. doi:10.1038/nature11632

30. Brion MJA, Shakhbazov K, Visscher PM. Calculating statistical power in Mendelian randomization studies. Int J Epidemiol. 2013;42(5):1497-1501. doi:10.1093/ije/dyt179

31. Adams M, Hill WD, Howard DM, et al. Factors associated with sharing email information and mental health survey participation in two large population cohorts. bioRxiv.

2018:471433. doi:10.1101/471433

32. Bowden J, Davey Smith G, Haycock PC, Burgess S. Consistent Estimation in Mendelian Randomization with Some Invalid Instruments Using a Weighted Median Estimator. Genet Epidemiol. 2016;40(4):304-314. doi:10.1002/gepi.21965

33. Traustadóttir T, Harman SM, Tsitouras P, et al. Long-term testosterone supplementation in older men attenuates age-related decline in aerobic capacity. J Clin Endocrinol Metab. 2018;103(8):2861-2869. doi:10.1210/jc.2017-01902

34. Bhasin S, Ellenberg SS, Storer TW, et al. Effect of testosterone replacement on measures 
of mobility in older men with mobility limitation and low testosterone concentrations: secondary analyses of the Testosterone Trials. Lancet Diabetes Endocrinol. 2018;6(11):879-890. doi:10.1016/S2213-8587(18)30171-2

35. Pierce BL, Ahsan H, VanderWeele TJ. Power and instrument strength requirements for Mendelian randomization studies using multiple genetic variants. Int J Epidemiol. 2011;40(3):740-752. doi:10.1093/ije/dyq151

36. Schumacher FR, Al Olama AA, Berndt SI, et al. Association analyses of more than 140,000 men identify 63 new prostate cancer susceptibility loci. Nat Genet. 2018;50(7):928-936. doi:10.1038/s41588-018-0142-8

37. Malik R, Chauhan G, Traylor M, et al. Multiancestry genome-wide association study of 520,000 subjects identifies 32 loci associated with stroke and stroke subtypes. Nat Genet. 2018;50(4):524-537. doi:10.1038/s41588-018-0058-3

38. Woo D, Falcone GJ, Devan WJ, et al. Meta-analysis of genome-wide association studies identifies 1q22 as a susceptibility locus for intracerebral hemorrhage. Am J Hum Genet. 2014;94(4):511-521. doi:10.1016/j.ajhg.2014.02.012

39. Scott RA, Scott LJ, Mägi R, et al. An Expanded Genome-Wide Association Study of Type 2 Diabetes in Europeans. Diabetes. 2017;66(11):2888-2902. doi:10.2337/db16-1253

40. Nikpay M, Goel A, Won H-H, et al. A comprehensive 1000 Genomes-based genomewide association meta-analysis of coronary artery disease. Nat Genet. 2015;47(10):11211130. doi:10.1038/ng.3396

41. Lambert JC, Ibrahim-Verbaas CA, Harold D, et al. Meta-analysis of 74,046 individuals identifies 11 new susceptibility loci for Alzheimer's disease. Nat Genet. 2013;45(12):1452-1458. doi:10.1038/ng.2802

42. Schwarzer G. meta: An R package for meta-analysis. R News. 2007;7(3):40-45.

43. Hemani G, Zheng J, Elsworth B, et al. The MR-Base platform supports systematic causal inference across the human phenome. Elife. 2018;7:e34408. doi:10.7554/eLife.34408

44. Adil A, Godwin M. The effectiveness of treatments for androgenetic alopecia: A systematic review and meta-analysis. J Am Acad Dermatol. 2017;77(1):136-141.e5. doi:10.1016/j.jaad.2017.02.054

45. Andriole GL, Bostwick DG, Brawley OW, et al. Effect of Dutasteride on the Risk of Prostate Cancer. N Engl J Med. 2010;362(13):1192-1202. doi:10.1056/NEJMoa0908127

46. Aukrust P, Ueland T, Gullestad L, Yndestad A. Testosterone: A Novel Therapeutic Approach in Chronic Heart Failure? J Am Coll Cardiol. 2009;54(10):928-929. doi:10.1016/j.jacc.2009.05.039

47. American Cancer Society. Cancer Facts \& Figures 2019. Atlanta; 2019.

48. Tacklind J, Fink HA, MacDonald R, Rutks I, Wilt TJ. Finasteride for benign prostatic hyperplasia. Cochrane Database Syst Rev. 2010;(10).

doi:10.1002/14651858.CD006015.pub3

49. De Conti P, Atallah ÁN, Arruda HO, Soares BG, El Dib RP, Wilt TJ. Intermittent versus continuous androgen suppression for prostatic cancer. Cochrane Database Syst Rev. 2007;(2). doi:10.1002/14651858.CD005009.pub2 
medRxiv preprint doi: https://doi.org/10.1101/19005132; this version posted August 29, 2019. The copyright holder for this preprint (which was not certified by peer review) is the author/funder, who has granted medRxiv a license to display the preprint in perpetuity.

It is made available under a CC-BY 4.0 International license .

\section{FIGURE LEGENDS}

Figure 1. Flowchart depicting overall study design. Free testosterone levels were calculated in males from the UK Biobank cohort. Then, genetic variants were tested for association with levels of CFT and carried forward if: genome-wide significant $\left(\mathrm{p}<5 \times 10^{-8}\right)$ and unassociated with SHBG $(p<0.05)$. These genetic variants represent genetically-predicted CFT (using variants unrelated to SHBG) and were tested for association with each of 23 health outcomes using Mendelian randomization. One-sample MR was performed using associations with 23 outcomes in males from the UK Biobank. Then, two-sample MR was performed using 10 dichotomous outcomes from independent cohorts with larger sample sizes. When male-specific summary statistics were available from independent cohorts, MR effect estimates were meta-analyzed. For statistically significant outcomes adjusting for multiple hypothesis testing $(\mathrm{p}<0.05 / 23)$, one-sample MR was repeated within age subgroups to identify differential effects in participants above versus below 65 years of age. CFT, calculated free testosterone; MR, Mendelian randomization; TT, total testosterone; SHBG, sex hormone-binding globulin 
medRxiv preprint doi: https://doi.org/10.1101/19005132; this version posted August 29, 2019. The copyright holder for this preprint (which was not certified by peer review) is the author/funder, who has granted medRxiv a license to display the preprint in perpetuity.

It is made available under a CC-BY 4.0 International license .

TABLES

Table 1. Effect of calculated free testosterone on 23 health outcomes in males from the UK Biobank

\begin{tabular}{|c|c|c|c|}
\hline Outcome & $\begin{array}{l}\text { Effect per } 0.1 \mathrm{nmol} / \mathrm{L} \text { increased CFT } \\
\qquad(95 \% \mathrm{Cl})\end{array}$ & P-value & $\begin{array}{l}\text { Sample Size } \\
\text { Cases/Controls }\end{array}$ \\
\hline \multicolumn{4}{|c|}{ Outcomes with Expected Clinical Benefits } \\
\hline Body Fat Percentage & $-1.86 \%(-2.35$ to -1.37$)$ & $1.56 \mathrm{E}-13$ & 154095 \\
\hline $\begin{array}{l}\text { Heel Bone Mineral } \\
\text { Density }\end{array}$ & 0.053 SD (0.038 to 0.068$)$ & 8.77E-12 & 90597 \\
\hline $\begin{array}{l}\text { Whole Body Fat-Free } \\
\text { Mass }\end{array}$ & $0.92 \mathrm{~kg}(0.27$ to 1.58$)$ & $5.67 \mathrm{E}-03$ & 154262 \\
\hline Handgrip Strength & $0.61 \mathrm{~kg}(-0.06$ to 1.28$)$ & 0.074 & 156403 \\
\hline $\begin{array}{l}\text { Accelerometer-based } \\
\text { Physical Activity }\end{array}$ & 0.90 milligravity (-0.43 to 2.23 ) & 0.19 & 30439 \\
\hline All Fracture & $\mathrm{OR}=0.82(0.6$ to 1.12$)$ & 0.21 & $9133 / 148098$ \\
\hline Depression & $\mathrm{OR}=1.28$ (0.84 to 1.95$)$ & 0.26 & $4725 / 152506$ \\
\hline All Dementia & $\mathrm{OR}=0.86(0.36$ to 2.1$)$ & 0.75 & $1003 / 156228$ \\
\hline \multicolumn{4}{|c|}{ Outcomes with Potential Adverse Effects } \\
\hline $\begin{array}{l}\text { Hematocrit } \\
\text { Percentage }\end{array}$ & $1.49 \%(1.24$ to 1.74$)$ & 3.49E-32 & 152893 \\
\hline Androgenic Alopecia & OR = 1.82 (1.55 to 2.14$)$ & 3.52E-13 & $70283 / 85757$ \\
\hline $\begin{array}{c}\text { Benign Prostatic } \\
\text { Hyperplasia }\end{array}$ & OR = 1.81 (1.34 to 2.44$)$ & $1.05 E-04$ & $10894 / 146337$ \\
\hline Prostate Cancer & $\mathrm{OR}=1.58$ (1.13 to 2.2$)$ & 7.71E-03 & $7586 / 149645$ \\
\hline Myocardial Infarction & $\mathrm{OR}=1.45$ (1.08 to 1.95$)$ & 0.013 & $9398 / 147833$ \\
\hline Hemoglobin A1c & $-0.47 \mathrm{mmol} / \mathrm{mol}(-1.02$ to 0.08$)$ & 0.096 & 149829 \\
\hline $\begin{array}{l}\text { Diastolic Blood } \\
\text { Pressure }\end{array}$ & $0.54 \mathrm{mmHg}(-0.21$ to 1.29$)$ & 0.16 & 143809 \\
\hline All Stroke & $\mathrm{OR}=1.32$ (0.87 to 2.02 ) & 0.19 & $4569 / 152662$ \\
\hline $\begin{array}{c}\text { Venous } \\
\text { Thromboembolism }\end{array}$ & $\mathrm{OR}=0.78$ (0.5 to 1.22$)$ & 0.28 & $4127 / 153104$ \\
\hline Type 2 Diabetes & $\mathrm{OR}=1.07$ (0.8 to 1.43$)$ & 0.65 & $11079 / 146152$ \\
\hline Glucose & $-0.02 \mathrm{mmol} / \mathrm{L}(-0.13$ to 0.09$)$ & 0.68 & 138308 \\
\hline Heart Failure & $\mathrm{OR}=1.09$ (0.7 to 1.69$)$ & 0.71 & $4288 / 152943$ \\
\hline Ischemic Stroke & $\mathrm{OR}=0.91$ (0.51 to 1.62$)$ & 0.75 & 2122/155109 \\
\hline Liver Fat & $-0.50 \%(-3.80$ to 2.80$)$ & 0.77 & 1595 \\
\hline $\begin{array}{l}\text { Systolic Blood } \\
\text { Pressure }\end{array}$ & $-0.18 \mathrm{mmHg}(-1.55$ to 1.20$)$ & 0.80 & 143805 \\
\hline
\end{tabular}

Bolded rows are significant adjusting for multiple hypothesis testing of 23 outcomes using Bonferroni correction $\left(\mathrm{p}<2.17 \times 10^{-3}\right)$

CFT, calculated free testosterone 


\section{Genome-wide association study}

Mendelian randomization (MR) analysis

Age-Stratified MR analysis
Unrelated, white British males from UK Biobank

$$
(N=158,870)
$$

Identify genetic determinants of calculated free testosterone

$$
(N=136,531)
$$

Effect of genetically-elevated free testosterone on $\mathbf{2 3}$ health outcomes in UK Biobank

Meta-analysis with MR effects in independent male-only cohorts

Testing for heterogeneous effects of genetically-elevated free testosterone stratified by age 